\title{
CALCULATION OF HEAT LOSS THROUGH THE PIPES OF THE INTERIOR CENTRAL HEATING SYSTEM
}

\author{
I. Giurca \\ Technical University of Cluj-Napoca, Faculty Building Services Engineering, Building Services Engineering Department, \\ B-dul. 21 Decembrie 1989, no. 128-130,Cluj-Napoca, Romania, e-mail: giurca_ioan@yahoo.com
}

Received: 15.09.2015 / Accepted: 10.10.2015 / Revised: 24.10.2015 / Available online: 15.12.2015

DOI: $10.1515 /$ jaes-2015-0018

KEY WORDS: central heating, residential buildings, thermal energy, energy audit

\begin{abstract}
:
The article presents aspects related to the calculation of heat loss through the pipes of the interior central heating system. The purpose of the article is to detail the local heat losses in case of central heating systems. Based on the conclusions of the article, we propose the modification of the calculation methodology related to the building energy audit.
\end{abstract}

\section{INTRODUCTION}

\subsection{Context}

As climate is changing and fossil fuel deposits are constantly diminishing, lowering energy consumption has become an important objective of the European Union states, including Romania. In order to achieve this goal, a series of legislative measures have been developed, their target being to limit energy consumption (Ionescu, 2011).

Buildings are responsible for $40-45 \%$ of the total energy consumption in Europe and China (and for about 30-40 \% worldwide) (Day, 2009).

It is well known that a major objective of all states is to decrease the energy consumption in order to protect the natural resources, and directly related to this aspect, to decrease the $\mathrm{CO}_{2}$ emissions in the atmosphere. These are also the objectives set in Directive no. 2010/31/UE on the energetic performance of buildings. This directive was transposed into the Romanian legislation in Law no. 372/2005 (Constantinescu, 2008), (Law 372, 2005).

\subsection{General Considerations}

The thermal calculation of the pipe networks represents a calculation related to the heat transfer between two fluids, separated by a wall. The purpose of the thermal calculation is either to determine the necessary width in order to satisfy certain imposed requirements (regulated values imposed to heat and temperature losses or certain values of the temperature at the surface of the thermal insulation), or to determine the heat and temperature losses for a certain thermal insulation (Athanasovici, 1981).

This paper represents a continuation of the study conducted by the author (Giurca, 2006, 2009; Naghiu, 2014) in the field of energetic audit.

\subsection{The purpose presented in the article}

The article presents aspects related to the calculation of heat loss through the pipes of the interior central heating system.

The purpose of the article is to detail the local heat losses in case of central heating systems. 


\subsection{The added value of the present article}

Based on the conclusions of the article, we propose the modification of the calculation methodology related to the building energy audit.

\section{MATERIALS AND METHODS}

\subsection{Calculation of total heat losses of a pipe}

The total amount of heat that a pipe loses in the environment is determined with the formulas:

$$
\mathrm{Qh}=\mathrm{q} \cdot \mathrm{L}+\sum \text { Qloc }
$$

or

$$
\mathrm{Qh}=\mathrm{qech} \cdot \mathrm{Le}=\mathrm{qech} \cdot(\mathrm{k} \cdot \mathrm{L}+\mathrm{l})
$$

where:

$\mathrm{Qh}=$ stands for the pipe's heat loss;

$\mathrm{q}=$ unitary heat losses of a thermally insulated pipe;

$\mathrm{L}=$ length of the pipe, in $\mathrm{m}$;

$\sum$ Qloc = local heat losses;

qech $=$ equivalent thermal flow;

$\mathrm{Le}=$ equivalent pipe length, in $\mathrm{m}$;

$\mathrm{k}=$ coefficient taking into account supplementary heat losses through the pipe's supporting elements (see table no. 1);

1 = length of the thermally insulated pipe, equaling the heat losses through the closing elements and through the pipe's joints, in $\mathrm{m}$ (Carabogdan, 1986).

\subsection{Key Determining heat losses through the related elements}

When referring to heat losses of a pipe system one must take into account not only the losses that correspond to the pipes, but also those corresponding to the related elements (valves, fittings, bases that are not insulated, etc.). In order to be able to take into account the related elements, one must consider an equivalent length (Mc 001/2, 2006).

\subsubsection{Determining the supplementary heat losses through the supporting elements of the pipe}

Supplementary heat losses through the supporting elements of the pipe are represented as percentages of the linear heat losses, and those respective values are presented in a table (see table no. 1).

\begin{tabular}{|l|c|c|}
\hline \multirow{2}{*}{$\begin{array}{c}\text { Pipe } \\
\text { supported by }\end{array}$} & \multicolumn{2}{|c|}{ K coefficient for } \\
\cline { 2 - 3 } & $\begin{array}{c}\text { pipes in enclosed } \\
\text { rooms }\end{array}$ & $\begin{array}{c}\text { pipes in open } \\
\text { air }\end{array}$ \\
\hline hanging & 1.10 & 1.15 \\
\hline propping & 1.15 & 1.20 \\
\hline
\end{tabular}

Table 1. Values of the K coefficient for determining heat losses through the supporting elements of the pipes (Athanasovici, 1981; Carabogdan, 1986)

\subsubsection{Determining heat losses through the valves' body, including through the joining flanges}

For losses through valves' bodies, including the flanges, the equivalent length taken into account depends on the thermal insulation degree. This value shall be added to the length of the pipes (Mc 001/2, 2006).

Further on, we shall present the data related to the way of determining heat losses through the valves' body, including through the joining flanges, according to the Romanian legislation in force, as well as in accordance with the specialized papers published in Romania, Germany, Belgium or France.

In table no. 2 we presented the equivalent length for the casings, in accordance with the Romanian calculation methodology, namely Mc 001/2-2006- Part II.

\begin{tabular}{|c|c|c|}
\hline $\begin{array}{c}\text { Valves also } \\
\text { including the } \\
\text { attachment } \\
\text { flanges }\end{array}$ & $\begin{array}{c}\text { Equivalent length }[\mathrm{m}] \\
\mathrm{ND} \leq 100 \mathrm{~mm}\end{array}$ & $\begin{array}{c}\text { Equivalent } \\
\text { length }[\mathrm{m}] \\
\mathrm{ND} \geq 100 \\
\mathrm{~mm}\end{array}$ \\
\hline not insulated & 4.0 & 6.0 \\
\hline insulated & 1.5 & 2.5 \\
\hline
\end{tabular}

Table 2. Equivalent length for casings (Mc 001/2, 2006)

In table no. 3 we presented the length of the thermally insulated pipe which represents the heat losses through the closing and joining elements, according to the

\begin{tabular}{|c|c|c|c|c|c|}
\hline & \multirow{2}{*}{ Element } & \multicolumn{2}{|c|}{ Pipes in enclosed rooms } & \multicolumn{2}{|c|}{ Pipes in open air } \\
\hline & & $\mathrm{t}=100^{\circ} \mathrm{C}$ & $\mathrm{t}=400{ }^{\circ} \mathrm{C}$ & $\mathrm{t}=100^{\circ} \mathrm{C}$ & $\mathrm{t}=400{ }^{\circ} \mathrm{C}$ \\
\hline \multirow[t]{2}{*}{ Casings } & $\mathrm{Di}=100 \mathrm{~mm}$ & 2.3 & 4.8 & 4.5 & 6.2 \\
\hline & $\mathrm{Di}=500 \mathrm{~mm}$ & 3.0 & 7.5 & 5.5 & 8.5 \\
\hline \multicolumn{2}{|c|}{ Joints through flanges } & \multicolumn{4}{|c|}{$1-1.5$} \\
\hline
\end{tabular}
Romanian specialized papers.

Table 3. Values of the "l" coefficient, the length of the thermally insulated pipe which represents the heat losses through the closing and joining elements, in $\mathrm{m}$ (Athanasovici, 1981; Carabogdan, 1986) 
According to the Romanian specialized papers (Voinescu, 1964), the "l" coefficient for the pipes located in enclosed rooms is the following:

- flange thermally not insulated, $3 \mathrm{~m}$;

- flange thermally insulated, $0.5 \mathrm{~m}$;

- cock or valve thermally not insulated, 5-7 m;

- cock or valve thermally insulated, $3 \mathrm{~m}$.

In table no. 4 we presented the equivalent length corresponding to valves and flanges thermally not insulated, according to the specialized papers from Germany.

\begin{tabular}{|l|c|c|c|}
\hline \multirow{2}{*}{ Name } & \multirow{2}{*}{$\mathrm{ND}$} & \multicolumn{2}{|c|}{ Water temperature } \\
\cline { 2 - 4 } & & $50^{\circ} \mathrm{C}$ & $100{ }^{\circ} \mathrm{C}$ \\
\hline \multirow{3}{*}{ Valves } & 25 & $0.5 \mathrm{~m}$ & $1.0 \mathrm{~m}$ \\
\cline { 2 - 4 } & 100 & $1.2 \mathrm{~m}$ & $2.5 \mathrm{~m}$ \\
\cline { 2 - 4 } & 300 & $3.0 \mathrm{~m}$ & $6.0 \mathrm{~m}$ \\
\hline \multirow{3}{*}{ Flanges } & 25 & $0.2 \mathrm{~m}$ & $0.4 \mathrm{~m}$ \\
\cline { 2 - 4 } & 100 & $0.5 \mathrm{~m}$ & $1.0 \mathrm{~m}$ \\
\cline { 2 - 4 } & 300 & $1.5 \mathrm{~m}$ & $3.0 \mathrm{~m}$ \\
\hline
\end{tabular}

Table 4. Thermally equivalent lengths of the valves and flanges thermally not insulated, in equivalent meters of pipe (Recknagel, 1996; Energie+, nd.b.)

And in table no. 5 we presented the equivalent pipe length corresponding to heat losses through valves and flanges, according to the specialized papers from Belgium.

\begin{tabular}{|c|c|}
\hline Name & $\begin{array}{c}\text { Equivalent } \\
\text { pipe length } \\
-\mathrm{m}-\end{array}$ \\
\hline Valves not insulated & 1.7 \\
\hline $\begin{array}{c}\text { Insulated valves }(6 \mathrm{~cm} \text { of } \\
\text { padding) }\end{array}$ & 0.17 \\
\hline Pair of flanges not insulated & 0.9 \\
\hline $\begin{array}{c}\text { Pair of flanges not insulated }(6 \\
\text { cm of padding) }\end{array}$ & 0.06 \\
\hline
\end{tabular}

Table 5. Equivalent pipe length for heat losses through valves and flanges (source: AIB, cited in paper (Energie+, nd.a.)

If the value of the "l" coefficient is not determined, the values of the " $\mathrm{K}$ " coefficient shall be increased with 0.05 (Carabogdan, 1986).

Heat losses through pipes may be represented directly as values, and therefore in table no. 6 we presented these values in accordance with the French specialized papers.

In table no. 7 we presented the values corresponding to heat losses through valves, according to the Belgian scholarly literature.

\begin{tabular}{|c|c|c|c|c|}
\hline $\mathrm{ND}$ & Threaded valve & Ball threaded valve & 2-way cock with flange & 3-way cock with flange \\
\hline $\mathrm{mm}$ & $\mathrm{W} /{ }^{\circ} \mathrm{C}$ & $\mathrm{W} /{ }^{\circ} \mathrm{C}$ & $\mathrm{W} /{ }^{\circ} \mathrm{C}$ & $\mathrm{W} /{ }^{\circ} \mathrm{C}$ \\
\hline 20 & 0.12 & 0.11 & & \\
\hline 32 & 0.17 & 0.18 & 1.65 & 2.59 \\
\hline 40 & & & & \\
\hline 50 & 0.25 & 0.32 & 3.37 & 3.63 \\
\hline 65 & & 0.59 & 4.46 & 5.71 \\
\hline 100 & & & 4.27 & \\
\hline
\end{tabular}

Table 6. Heat loss values recommended for a temperature difference of one degree between the thermal agent and the air (COSTIC, nd)

\begin{tabular}{|c|c|c|c|c|}
\hline Inner diameter & Outside diameter & Not-insulated valve & Insulated valve & Savings \\
\hline toli & $\mathrm{mm}$ & $\mathrm{W} / \mathrm{m}^{2}$ & $\mathrm{~W} / \mathrm{m}^{2}$ & $\mathrm{~W} / \mathrm{m}^{2}$ \\
\hline $1 / 2$ & 21 & 48 & 17 & 31 \\
\hline 1 & 33 & 88 & 31 & 57 \\
\hline $11 / 2$ & 48 & 124 & 43 & 81 \\
\hline 2 & 60 & 158 & 55 & 103 \\
\hline 3 & 89 & 226 & 79 & 147 \\
\hline 4 & 114 & 292 & 102 & 190 \\
\hline 5 & 140 & 358 & 125 & 233 \\
\hline 6 & 169 & 420 & 147 & 273 \\
\hline
\end{tabular}

Table 7. Heat losses through valves (Simon, 2010) 
In Figure 1-4 we presented the heat losses through valves, as presented by the French association COSTIC in the paper (COSTIC, nd).

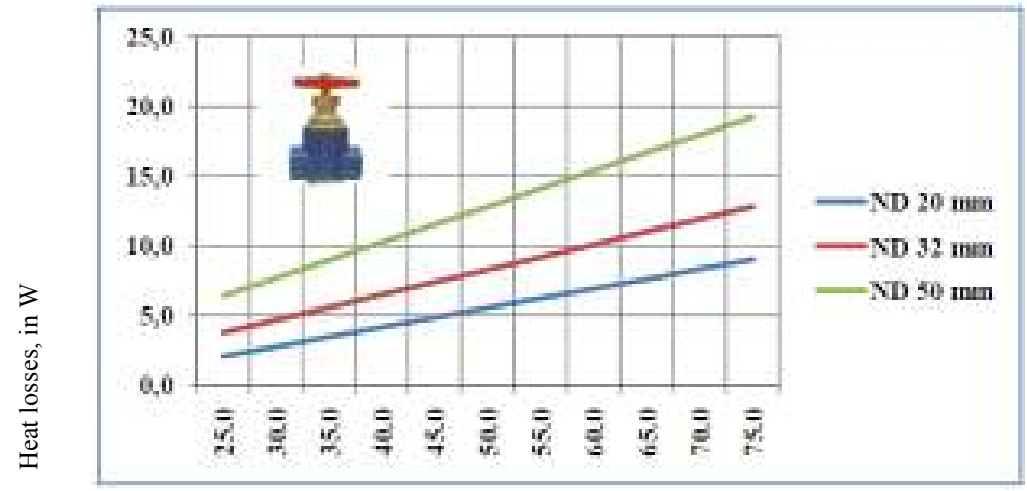

Temperature difference between the thermal agent and the air, in $\mathrm{K}$

Figure 1. Nomogram for determining heat losses through threaded valve

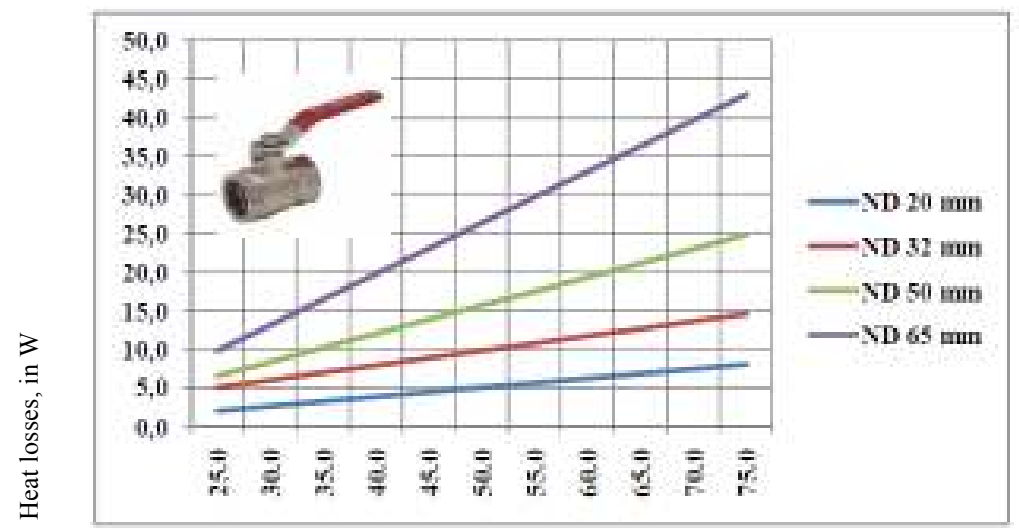

Temperature difference between the thermal agent and the air, in $\mathrm{K}$

Figure 2. Nomogram for determining heat losses through ball valves

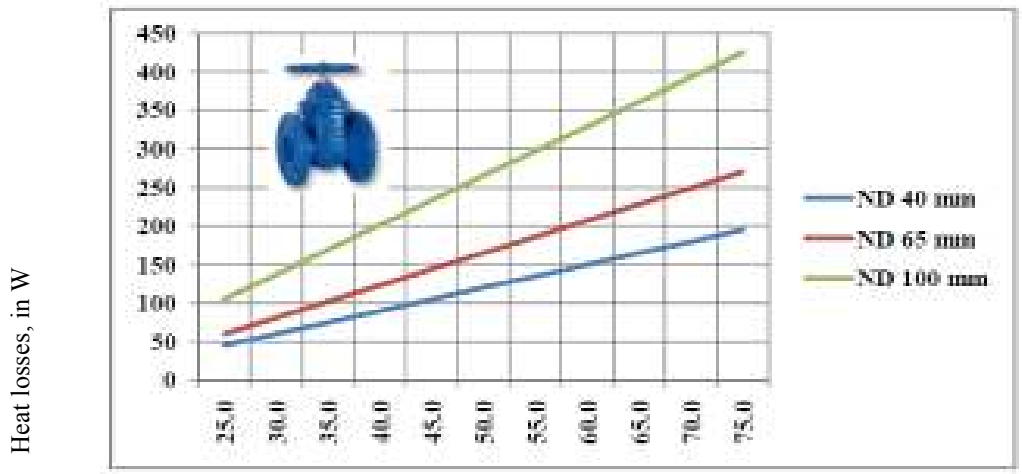

Temperature difference between the thermal agent and the air, in $\mathrm{K}$

Figure 3. Nomogram for determining heat losses through flanged ball valves 


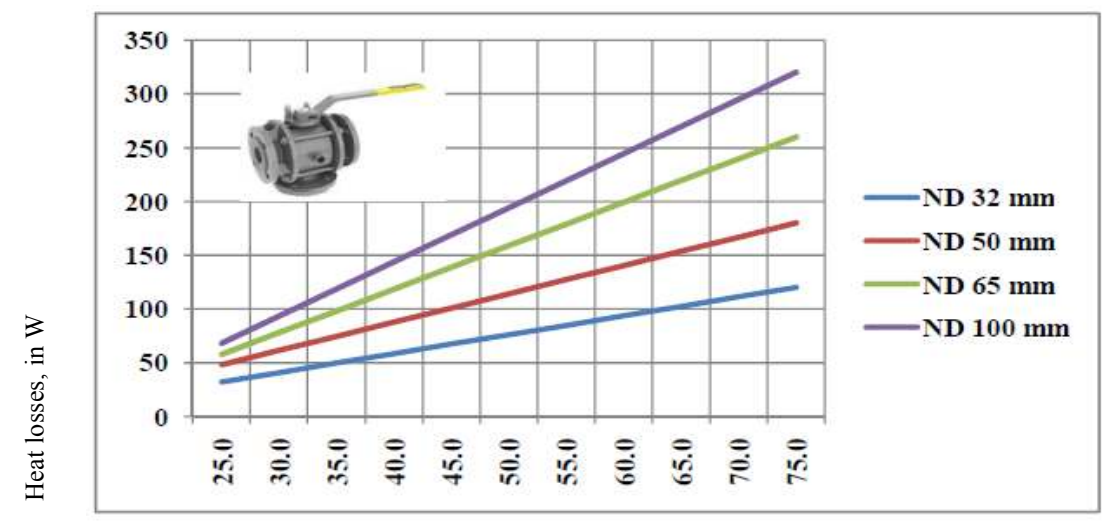

Temperature difference between the thermal agent and the air, in $\mathrm{K}$

Figure 4. Nomogram for determining heat losses through 3 way flanged valves

\section{CASE STUDY, RESULTS AND DISCUSSION}

\subsection{Case Study}

Further on, we are presenting a case study concerning the heat losses that occur in case of an interior central heating system of a block of flats located in Bucharest and administered by the Owners' Association.

The building has a parallelepiped shape, consists of 2 sections, each of these sections being composed of an underground floor, a first floor and 3 floors. In plan, the building's dimensions are $34.90 \mathrm{~m} \times 13.00 \mathrm{~m}$, with a total built surface of $1814.88 \mathrm{~m}^{2}$.

The block has 24 flats, namely 3 flats on each floor that is 12 flats on each section (Mc 001/4, 2009).

\section{Hypotheses:}

- the number of yearly heating hours is of 5736 hours/year;

- the average temperature of the heating agent is of 70 ${ }^{\circ} \mathrm{C}$;

- the average temperature of the underground floor is of $8.73{ }^{\circ} \mathrm{C}$;

- the average interior temperature is of $20{ }^{\circ} \mathrm{C}$;

- the pipes located in the underground floor are thermally insulated;

- the pipes located in the apartments are not thermally insulated.

\subsection{Results}

Based on the above hypotheses and based on the calculation methodology, we made the calculations using the following bibliography in order to determine the heat losses through the valves:

- Romanian legislation;
- specialized papers from Belgium; - specialized papers from France.

Steps pipe heat loss calculation are shown in Figure 5.

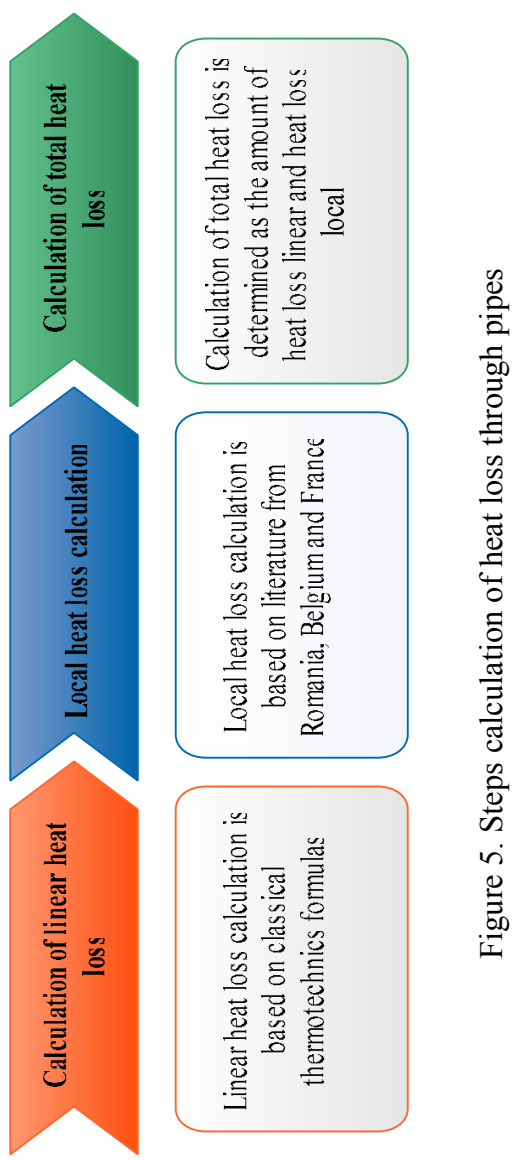


The results of the calculations are synthetically presented in table no. 8 , table no. 9 , table no. 10 and table no. 11.

\begin{tabular}{|c|c|c|c|c|c|c|c|c|c|}
\hline $\begin{array}{c}\text { Pipe } \\
\text { destination }\end{array}$ & di & $\begin{array}{c}\text { Unitary heat } \\
\text { losses of a } \\
\text { thermally } \\
\text { insulated pipe, } \\
\text { q }\end{array}$ & L & $\begin{array}{c}\text { Total } \\
\text { linear heat } \\
\text { loss }\end{array}$ & $\begin{array}{l}\text { Number } \\
\text { of valves }\end{array}$ & 1 & $\begin{array}{c}\text { Equivalent pipe } \\
\text { length for heat } \\
\text { losses through } \\
\text { valves }\end{array}$ & $\begin{array}{l}\text { Total loss of } \\
\text { local heat }\end{array}$ & $\begin{array}{c}\text { Total loss } \\
\text { of heat }\end{array}$ \\
\hline & $\mathrm{m}$ & $\mathrm{kWh} / \mathrm{m}$ an & $\mathrm{m}$ & $\mathrm{kWh} / \mathrm{an}$ & pcs. & $\mathrm{m} / \mathrm{pcs}$. & $\mathrm{m}$ & $\mathrm{kWh} / \mathrm{an}$ & $\mathrm{kWh} / \mathrm{an}$ \\
\hline $\begin{array}{l}\text { Distribution } \\
\text { pipeline }\end{array}$ & 0.04 & 76.849 & 206.28 & 15,852 & 6 & 3 & 18 & 1,383 & 17,236 \\
\hline Columns & 0.025 & 51.828 & 254.4 & 13,185 & 48 & 3 & 144 & 7,463 & 20,648 \\
\hline $\begin{array}{l}\text { Connecting } \\
\text { pipes to } \\
\text { radiators }\end{array}$ & 0.015 & 58.145 & 960 & 55,819 & 64 & 6 & 384 & 22,328 & 78,146 \\
\hline Total & & & $1,420.68$ & 84,856 & 118 & & 546 & 31,174 & 116,030 \\
\hline
\end{tabular}

Table 8. Calculation of heat loss through pipes according to literature in Romania

\begin{tabular}{|c|c|c|c|c|c|c|c|c|c|}
\hline $\begin{array}{c}\text { Pipe } \\
\text { destination }\end{array}$ & di & $\begin{array}{l}\text { Unitary heat } \\
\text { losses of a } \\
\text { thermally } \\
\text { insulated } \\
\text { pipe, q }\end{array}$ & $\mathrm{L}$ & $\begin{array}{c}\text { Total } \\
\text { linear heat } \\
\text { loss }\end{array}$ & $\begin{array}{l}\text { Number } \\
\text { of valves }\end{array}$ & 1 & $\begin{array}{c}\text { Equivalent pipe } \\
\text { length for heat } \\
\text { losses through } \\
\text { valves }\end{array}$ & $\begin{array}{l}\text { Total loss of } \\
\text { local heat }\end{array}$ & $\begin{array}{c}\text { Total loss } \\
\text { of heat }\end{array}$ \\
\hline & $\mathrm{m}$ & $\mathrm{kWh} / \mathrm{m}$ an & $\mathrm{m}$ & $\mathrm{kWh} / \mathrm{an}$ & pcs. & $\mathrm{m} / \mathrm{pcs}$. & $\mathrm{m}$ & $\mathrm{kWh} / \mathrm{an}$ & $\mathrm{kWh} / \mathrm{an}$ \\
\hline $\begin{array}{l}\text { Distribution } \\
\text { pipeline }\end{array}$ & 0.04 & 76.849 & 206.28 & 15,852 & 6 & 0.17 & 1.02 & 78 & 15,931 \\
\hline Columns & 0.025 & 51.828 & 254.4 & 13,185 & 48 & 0.17 & 8.16 & 423 & 13,608 \\
\hline $\begin{array}{l}\text { Connecting } \\
\text { pipes to } \\
\text { radiators }\end{array}$ & 0.015 & 58.145 & 960 & 55,819 & 64 & 1.7 & 108.8 & 6,326 & 62,145 \\
\hline Total & & & $1,420.68$ & 84,856 & 118 & 2.04 & 117.98 & 6,827 & 91,684 \\
\hline
\end{tabular}

Table 9. Calculation of heat loss through pipes according to literature in Belgium

\begin{tabular}{|c|c|c|c|c|c|c|c|c|c|c|}
\hline $\begin{array}{c}\text { Pipe } \\
\text { destination }\end{array}$ & di & $\begin{array}{c}\text { Unitary heat } \\
\text { losses of a } \\
\text { thermally } \\
\text { insulated pipe, } \\
\text { q }\end{array}$ & $\mathrm{L}$ & $\begin{array}{c}\text { Total } \\
\text { linear heat } \\
\text { loss }\end{array}$ & $\begin{array}{l}\text { Number } \\
\text { of valves }\end{array}$ & 1 & $\Delta \mathrm{T}$ & $\mathrm{tH}$ & $\begin{array}{c}\text { Total loss of } \\
\text { local heat }\end{array}$ & $\begin{array}{l}\text { Total loss of } \\
\text { heat }\end{array}$ \\
\hline & $\mathrm{m}$ & $\mathrm{kWh} / \mathrm{m}$ an & $\mathrm{m}$ & $\mathrm{kWh} / \mathrm{an}$ & pcs. & $\mathrm{W} /{ }^{\circ} \mathrm{C}$ & K & $\mathrm{h} /$ year & $\mathrm{kWh} / \mathrm{an}$ & $\mathrm{kWh} / \mathrm{an}$ \\
\hline $\begin{array}{l}\text { Distribution } \\
\text { pipeline }\end{array}$ & 0.04 & 76.849 & 206.28 & 15,852 & 6 & 0.32 & 61.27 & 5,736 & 675 & 16,527 \\
\hline Columns & 0.025 & 51.828 & 254.4 & 13,185 & 48 & 0.18 & 50 & 5,736 & 2,478 & 15,663 \\
\hline $\begin{array}{l}\text { Connecting } \\
\text { pipes to } \\
\text { radiators }\end{array}$ & 0.015 & 58.145 & 960 & 55,819 & 64 & 0.11 & 50 & 5,736 & 2,019 & 57,838 \\
\hline Total & & & $1,420.68$ & 84,856 & 118 & & & & 5,172 & 90,028 \\
\hline
\end{tabular}

Table 10. Calculation of heat loss through pipes according to literature in France 


\begin{tabular}{|l|r|r|r|r|r|}
\hline \multirow{2}{*}{ Method } & $\begin{array}{c}\text { Total linear heat } \\
\text { loss }\end{array}$ & $\begin{array}{c}\text { Total loss of local } \\
\text { heat }\end{array}$ & $\begin{array}{c}\text { Total loss of } \\
\text { heat }\end{array}$ & $\begin{array}{c}\text { Linear losses } \\
\text { weight }\end{array}$ & $\begin{array}{c}\text { Local losses } \\
\text { weight }\end{array}$ \\
\cline { 2 - 6 } & $\mathrm{kWh} / \mathrm{an}$ & $\mathrm{kWh} / \mathrm{an}$ & $\mathrm{kWh} / \mathrm{an}$ & \multicolumn{1}{c}{$\%$} & $\%$ \\
\hline Romania & 84,856 & 31,174 & 116,030 & $73.1 \%$ & $26.9 \%$ \\
\hline Belgium & 84,856 & 6,827 & 91,684 & $92.6 \%$ & $7.4 \%$ \\
\hline France & 84,856 & 5,172 & 90,028 & $94.3 \%$ & $5.7 \%$ \\
\hline
\end{tabular}

Table 11. Values of heat losses

where:

di represents the inner diameter of the pipe, in $\mathrm{m}$;

$\Delta \mathrm{t}$ - temperature difference between the thermal agent and the air, in $\mathrm{K}$;

$\mathrm{tH}$ - the annual number of hours of heating, $\mathrm{h} /$ year.

The results obtained are also presented graphically (figure 6 and figure 7).

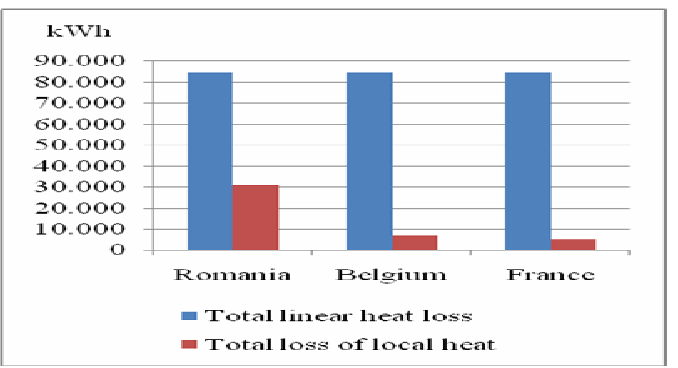

Figure 6. Values of heat losses

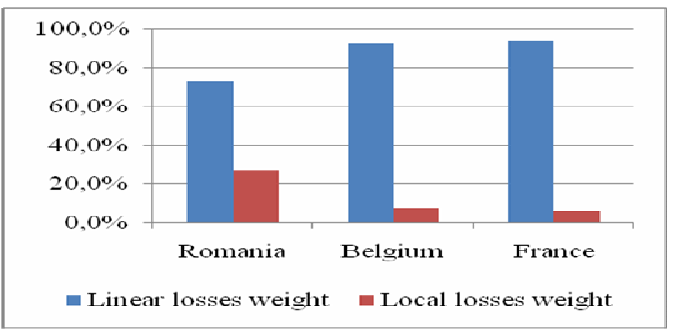

Figure 7. Weight of heat losses

\subsection{Discussion}

From the facts presented above, it results that:

- local heat losses range between 5.7...26.9 \% from total heat losses;
- the values obtained for the local heat losses may differ, depending on the bibliography used when making the calculations.

\section{CONCLUSIONS}

a) Conclusions derived from the article:

- The use of the calculation method presented above allows us to calculate more precisely the heat losses through valves, depending on the constructive type of the valve used and depending on the temperature difference between the thermal agent and the air.

- We notice that using different bibliographic sources may lead to obtaining different local heat losses, for the same interior central heating system.

- Considering that the local heat losses may have significant values, we recommend that in the preliminary calculations, one should supplement the local heat losses. According to the recommendations of the Romanian specialized papers, in case of interior heating systems, the heat losses through:

- pipe supporting elements represent about 10$15 \%$ of the linear heat losses;

- closing elements and pipe joints represent about $5 \%$ of the linear heat losses.

b) Contribution of the present work synthesis:

- The article presents aspects related to the calculation of heat loss through the pipes of the interior central heating system.

- The purpose of the article is to detail the local heat losses in case of central heating systems. 
c) The possibility of practical use of the study results:

- The conclusions of this study are useful both for the specialists who want to obtain the energy auditor license for buildings as well as for elaborating energy audit projects for buildings.

d) Outlook:

- Based on the conclusions of the article, we propose the modification of the calculation methodology related to the building energy audit.

\section{REFERENCES}

Athanasovici, V., Muşatescu, V., Dumitrescu, I., S., 1981. Termoenergetică industrială şi termoficare (Industrial thermoenergetics and thermofication). Editura Didactică şi Pedagogică, Bucureşti, pp. 290-291; 295.

Carabogdan, I., G., 1986. Manualul inginerului termotehnician. Volumul III (Manual of the thermotechnician engineer. Volume III). Editura Tehnică, Bucureşti, pp. 696-697.

Constantinescu, D., Perianu, C., Petran, H., Petcu, C., 2008. Estimarea analitică a performanței energetice a clădirilor de locuit existente - metoda simplificată (Analytical Assessment of the Energy Performance of Existent Residential Buildings - the Simplified Method). Revista Construcții, no. 2, p. 26.

Day, AR., Ogumka, P., Jones, PG., Dunsdon, A., 2009. The use of the planning system to encourage low carbon energy technologies in buildings. Renewable Energy, Volume 34, Issue 9, pp. 2016-2021.

Giurca, I., 2006. Analiza economică a măsurilor de modernizare energetică a clădirilor existente (Economic analysis of measures to modernize the existing building energy). În: Conferința „Ştiința Modernă şi Energia”, Ediția a XXV-a; 18-19 mai 2006, Cluj-Napoca, România. Risoprint, Cluj-Napoca, pp. 347-350.

Giurca, I. 2009. Contribuții privind alimentarea cu energie termică a ansamblurilor de locuințe, utilizând agenți termici cu parametri scăzuți (Contributions to thermal energy supplies of building assemblies by using thermal agents with low parameters), Teză de doctorat, Universitatea Tehnică din Cluj-Napoca, Cluj-Napoca. Ionescu, A. M., 2011. Cercetări privind consumul de energie pentru climatizarea clădirilor (Research works on the energy consumption for buildings' acclimatization),
Teză de doctorat, Universitatea Tehnică de Construcții Bucureşti, Bucureşti, p. 6.

Naghiu, G. S., Giurca, I., 2014. Considerations related to economic efficiency indices in case of energy audit for buildings. Annals of the "Constantin Brâncuşi" University of Târgu Jiu. Economy Series, Issue 5, pp. 9297.

Recknagel, H., Sprenger, E., Schramek, E-R., 1995. Taschenbuch für heizung + klimatechnik. Oldenbourg, 94/95, pp. 824.

Simon, D., 2010. Cahier technique $\mathrm{n}^{\circ} 9$. Economies d'énergie dans l'industrie. Service public de Wallonie, p. 4.

Voinescu, V., Niculescu, N., Lăzărescu, L., 1964. Îndrumătorul instalatorilor (Plumbers' Guide). Editura Tehnică, Bucureşti, pp. 506-509.

*** COSTIC, nd. Developpements. „DEV. 6 L'optimisation des circuits de chaufferies".

*** Energie+, nd.a. Évaluer l'efficacité énergétique de la distribution de chaleur. Louvain, Belgique http://www.energieplus-lesite.be/index.php?id=10904 (view at 9 Sep. 2015).

*** Energie+, nd.b. Les pertes de chaleur des conduites et vannes non isolées Louvain, Belgique http://www.energieplus-lesite.be/index.php?id=11002 (view at 9 Sep. 2015).

*** Legea nr. 372, 2005. Lege privind performanța energetică a clădirilor (Law 372/2005 on the energy performance of buildings).

*** Mc 001/2, 2006. Metodologia de calcul al performanței energetice a clădirilor. Partea a II-a Performanța energetică a instalațiilor din clădiri (Calculation methodology of the energy performance of buildings. Part II - Energy performance of installations from buildings), pp. 34-35.

*** Mc 001/4, 2009. Metodologie de calcul al performanței energetice a clădirilor. Partea a IV-a Breviar de calcul al performanței energetice a clădirilor şi apartamentelor (Calculation methodology of the energy performance of buildings. Part IV - Calculation for the energy performance of buildings and apartments), p. 84 . 